\title{
Minimum water requirement for social and economic development
}

Author details:

Jonathan Chenoweth, Centre for Environmental Strategy, University of Surrey, Guildford, Surrey, GU2 7XH, UK.

Email: j.chenoweth@surrey.ac.uk

Tel: +44 1483689096

Fax: +44 1483686671 


\section{Minimum water requirement for social and}

\section{economic development}

There is no common understanding of the minimum per capita fresh water requirement for human health and economic and social development. Existing estimates vary between 20 litres and 4,654 litres per capita per day, however, these estimates are methodologically problematic as they consider only human consumptive and hygiene needs, or they consider economic needs but not the effects of trade. Reconsidering the components of a minimum water requirement estimate for human health and for economic and social development suggests that a country requires a minimum of 135 litres per person per day. With all countries except Kuwait having much greater water resources than this, water scarcity alone need not hinder development. Given the steadily decreasing cost of desalination together with the relatively small amount of water required per capita to permit social and economic development, desalination should be affordable where necessary for all but the very least economically developed countries where local naturally occurring freshwater resources are insufficient and saline water is available.

Key words: water scarcity, water requirements, human development, economic development, health, hygiene. 


\section{Introduction}

In the Millennium Declaration of the UN General Assembly in 2000 a commitment was made to halve by 2015 the global proportion of people without access to safe drinking water [1]. The international community both confirmed and extended this commitment in the 2002 Johannesburg Declaration on Sustainable Development [2].

The World Health Organisation (WHO) in its Guidelines for Drinking-Water Quality assumes an adult requires approximately two litres of drinking water per day, although it acknowledges that water intake can vary significantly [3]. Improving access to safe drinking water and ultimately achieving universal access to safe drinking water would represent an important achievement. However, ensuring that all people have access to sufficient safe water to meet their drinking requirement alone, will not allow other basic development goals, such as poverty eradication nor the sustainable development of society as a whole, to be met.

Article 25 of the 1948 Universal Declaration of Human Rights states that "[e]veryone has the right to a standard of living adequate for the health and well-being of himself and of his family, including food, clothing, housing and medical care and necessary social services". While not explicitly stating that there was a human right to water, the human right to water was implied since access to water is a key factor that determines health and well-being. Access to water as an independent human right was recognised in 2002 [4], and as Brooks [5] notes, few people argue against the principle of there being a human right to water for 
basic households uses even if many countries fail to achieve this in practice. Brooks argues, however, that the concept of a human right to water should be enlarged to include a right to water for household food production and to maintain functioning ecosystems, issues which are returned to later in this paper.

The human need for water clearly goes beyond basic drinking requirements yet despite the perception that global water resources are in crisis, in part due to growing water scarcity, [6], there is no common understanding of what is the minimum amount of fresh water per capita actually required to satisfy human health and economic development, permit poverty eradication, and ideally, enable a high quality of life for all. In part this lack of common understanding is due to disagreement about which components of water usage should be included in such an estimate. This paper thus seeks to answer the question - what components of water usage should be included in an estimate of the minimum amount of water that is required to permit social and economic development in a society? An answer to this question then allows an actual estimate of the minimum amount of water required to permit social and economic development to be calculated.

The magnitude of the minimum water requirement for social and economic development has implications for the role that of desalination in assisting with meeting the Millennium Development Goals relating to basic water provision and poverty reduction. Extremely modest minimum water requirements suggests that desalination already holds significant potential for facilitating these requirements to be met in almost all water scarce regions, including low income countries. A large minimum water requirement for economic and 
social development, however, suggests that desalination is likely to be too costly to perform this role in low income countries even if it may have a role in water provision for meeting human health and hygiene needs in some low income countries. In such countries the economy would be unable to pay the cost of meeting a large minimum water requirement from desalination.

The magnitude of minimum water requirements for social and economic development also has implications for international negotiations over water resources. The two most authoritative expressions of international water resources law are the Helsinki rules of the International Law Association, published in 1967, and the 1997 Convention on the Law of the Non-navigational Uses of International Watercourses developed by the International Law Commission of the United Nations [7]. According to the Helsinki rules, one of the factors to consider when determining the equitable share of the uses of an international watercourse is the social and economic requirements of each riparian nation [8]. The 1997 Convention similarly list the socio-economic needs of the watercourse nations as one of the factors to be considered when determining the equitable use of an international watercourse [9]. The 1997 Convention also states that riparian countries must refrain from causing "significant harm" to the other riparian countries of an international watercourse; denying a country sufficient water to permit social and economic development could be considered as causing significant harm to that country. Thus, any widely accepted estimate of minimum water requirements for social and economic development may in some circumstances have significant implications for determining the absolute minimum amount of water a country is entitled to under international law from a shared watercourse. 
In order to determine what components of water usage should be included in an estimate of minimum water requirements this paper begins by examining existing estimates of water requirements and their constituent components, before considering broadly how humans use water and how societies adapt to water scarcity. Conceptual frameworks for estimating a minimum water requirement are then proposed based upon how societies use water and adapt to water scarcity, after which the validity of the proposed frameworks are tested through the development of an estimate of actual minimum water requirements. Other significant uses of water not incorporated directly in the conceptual framework are then considered before the paper concludes on the global implications of the minimum water estimate for meeting basic human needs and national development.

\section{Existing estimates of per capita water requirements}

A range of estimates of per capita water requirements have been developed, ranging from 20 litres per capita per day (1/c/d) through to 4,654 l/c/d (1,700 cubic metres per capita per year $\left.\left(\mathrm{m}^{3} / \mathrm{c} / \mathrm{y}\right)\right)$. The WHO and UNICEF [15] in their global assessment of water supply adopted the figure of $20 \mathrm{l} / \mathrm{c} / \mathrm{d}$ for domestic hygiene purposes from a source located within one kilometre of a person's dwelling and coming from one of a range of technologies generally considered capable of supplying safe water. No clarification was given, however, about how their estimate of $20 \mathrm{l} / \mathrm{c} / \mathrm{d}$ was derived. 
Gleick [16] argues that at least $50 \mathrm{l} / \mathrm{c} / \mathrm{d}$ are required to meet human and ecological needs, namely $5 \mathrm{l} / \mathrm{c} / \mathrm{d}$ for drinking in tropical climates, $20 \mathrm{l} / \mathrm{c} / \mathrm{d}$ for sanitation, $15 \mathrm{l} / \mathrm{c} / \mathrm{d}$ for bathing and 10 litres 1/c/d for food preparation [16].

Howard and Bartram [17] argue that $7.5 \mathrm{l} / \mathrm{c} / \mathrm{d}$ can be calculated as the basic minimum water requirement to meet direct human consumptive needs, of which $2 \mathrm{l} / \mathrm{c} / \mathrm{d}$ is required for food preparation. When water required for maintaining human hygiene is considered also, calculating a minimum water requirement becomes less precise as the effective use of water for hygiene purposes is more important than the quantity used, with only a very small quantity of water required to prevent water acting as an absolute constraint on hygiene [17]. With basic access of approximately $20 \mathrm{l} / \mathrm{c} / \mathrm{d}\left(7.3 \mathrm{~m}^{3} / \mathrm{c} / \mathrm{y}\right)$ it is unlikely that all water requirements for hygiene will be met; at $50 \mathrm{l} / \mathrm{c} / \mathrm{d}\left(18.3 \mathrm{~m}^{3} / \mathrm{c} / \mathrm{y}\right)$ (intermediate access) most requirements can be met, and at $100 \mathrm{l} / \mathrm{c} / \mathrm{d}\left(36.5 \mathrm{~m}^{3} / \mathrm{c} / \mathrm{y}\right)$ (optimum access) all requirements can be met [17].

Higher estimates of water requirements also consider economic uses of water. Shuval [18] suggests that a figure of $274 \mathrm{l} / \mathrm{c} / \mathrm{d}\left(100 \mathrm{~m}^{3} / \mathrm{c} / \mathrm{y}\right)$ is adequate to meet non-agricultural water requirements and $68 \mathrm{l} / \mathrm{c} / \mathrm{d}\left(25 \mathrm{~m}^{3} / \mathrm{c} / \mathrm{y}\right)$ for essential fresh food production, with this second water requirement able to be augmented with recycled wastewater. Exactly how these figures were derived is not clear but they approximate the per capita domestic and industrial water consumption found in the author's native Israel [10]. 
Falkenmark [19] argues that $1,369 \mathrm{l} / \mathrm{c} / \mathrm{d}(500 \mathrm{~m} 3 / \mathrm{c} / \mathrm{y})$ is the minimum required to run a modern society living in semi-arid conditions, with 1,095 1/c/d $(400 \mathrm{~m} 3 / \mathrm{c} / \mathrm{y})$ required for irrigation, and $274 \mathrm{l} / \mathrm{c} / \mathrm{d}(100 \mathrm{~m} 3 / \mathrm{c} / \mathrm{y})$ for domestic and industrial needs. This figure suggested by Falkenmark corresponds with the water availability figures she cites for Israel at that time. While considering agricultural self-sufficiency needs Falkenmark provides higher thresholds for water stress $(4,564 \mathrm{l} / \mathrm{c} / \mathrm{d}-1667 \mathrm{~m} 3 / \mathrm{c} / \mathrm{y}$, usually rounded to 1700 $\mathrm{m} 3 / \mathrm{c} / \mathrm{y}$ ), and water scarcity threatening economic development, human health or well-being $(2,738 \mathrm{l} / \mathrm{c} / \mathrm{d}-1000 \mathrm{~m} 3 / \mathrm{c} / \mathrm{y})$. The World Water Assessment Programme [6] suggested that $4,654 \mathrm{l} / \mathrm{c} / \mathrm{d}(1700 \mathrm{~m} 3 / \mathrm{c} / \mathrm{y})$ of drinking water is required for an active and healthy human life but did not indicate how this remarkably large estimate was derived.

The different estimates of minimum water requirements were developed with a range of purposes in mind. None, however, are appropriate nor assess in a methodological defensible manner the amount of water required to permit social and economic development in a country. The Falkenmark index attempts to do this to some extent, but the estimate of the amount of water required to run a modern society in semi-arid conditions is based off a country (Israel) which has since demonstrated, due to growing water scarcity, that it can operate effectively with significantly less water resources per capita than this estimate suggests, and the estimates based on agricultural self-sufficiency do not allow for the effects of international trade on water requirements. See Table 1 for a list of water requirement estimates. 
[Table 1 about here]

\section{Forming an estimate of minimum water requirements for social and economic development}

\subsection{Adaptation to water scarcity through international trade}

Humans require fresh water for three broad uses, namely domestic use which includes drinking, washing, food preparation and general hygiene, agricultural use in order to produce food, and industrial use for non-agricultural commercial activities. As revealed in section 2, the inclusion of agricultural needs significantly raises minimum water requirement estimates. Presently, 70 percent of total global fresh water withdrawals are used for agriculture [10]. Countries adapt to reduced water availability by using their water resources more efficiently, through reduced wastage, and allocating water to more productive economic uses.

One specific means of adapting to increasing water scarcity is through trade - a country can increasing switch to food imports, frequently termed "virtual water", in order to satisfy its basic food supply needs [11]. Water resources and food security are no longer clearly linked as even the least developed countries now participate to varying degrees in the global food market. For example, in 2002 imports made up 20 percent of the grain supply across sub-Saharan Africa, the region with the lowest average per capita incomes [12]. Looking at individual countries, the picture is similar. Of the ten countries ranked lowest on 
the Human Development Index of the UNDP, grain imports made up 44 percent of domestic supply in Sierra Leone, 30 percent in Mozambique, 22 percent in Burundi, and 18 percent in the Central African Republic [12].

Least developed countries have since the late 1980s become major net importers of agricultural produce, with imported food making up more than ten percent of total food consumption when measured in calorie terms [13]. Food aid accounts for less than twenty percent of total food imports in least developed countries, with such countries spending on average approximately five percent of their GDP on food imports, or approximately 55 percent of their foreign exchange earnings [13]. However, while food imports may be relatively expensive for some water scarce countries, importing grains to meet basic food needs is much cheaper than importing or desalinating the volume of water required to grow the same quantity of grain locally. Food imports allow countries to reallocate limited water to uses providing a higher economic return [11].

While having plentiful water to support agricultural development is obviously beneficial and many countries still maintain significant agricultural sectors for a variety of political or social reasons, the functioning of a global food market means that the validity of assessing minimum water requirements on the basis of national food self sufficiency is doubtful. Sufficient water for agriculture is required globally, but when considering minimum water requirements for human development in specific water scarce countries, it is water for domestic needs and a non-agricultural economy that is vital. However, the minimum amount of water required for this has not been systematically calculated. 
Just as an increasing number of countries depend upon grain imports to meet their national food needs and thus balance water availability with water demands, functioning global markets for industrial goods and services also allow water scarce countries to trade for goods that contain significant quantities of embedded water. Chapagain and Hoekstra [14] estimate that embedded water content of industrial products average 80 litres per US\$ but there is considerable variation between countries which reflects the varying water intensity of different industries compared to the value of their output. By comparing the flows of embedded water in goods and services traded, it is possible to estimate the water footprint of countries [14]. While the water footprint of a country indicates the total amount of water consumed by the citizens of a country, directly and indirectly, it does not show the actual amount of water required internally in a country to meet human health needs and the economic development that allows countries to trade for water intensive products imported from more water plentiful regions.

\subsection{The conceptual framing of an estimate of minimum water requirements}

Existing estimates of basic human water requirements which are based on specific quantities of water required for basic domestic functions are much lower than those based upon water quantities actually used by a modern society using its water resources relatively prudently, and at least an order of magnitude lower than water requirements for satisfying domestic, industrial and agricultural needs so that a country can avoid the use of virtual water and achieve food self security based upon irrigated agriculture. The lower estimates of minimum water requirements give a clear indication of the absolute minimum water 
requirements to support adequate human health and hygiene but do not show the minimum amount of water required domestically to allow a high quality of life. The higher estimates allow for economic development but appear to be based upon the water consumption patterns of a single water scarce developed country (Israel).

Estimating the water required to sustain a high level of development is problematic as it requires value judgements about the desired level of economic development. A variety of terminologies, such as developed and developing, first-world and third-world, and the North and the South, are commonly used to categorise countries according to whether or not they are seen as being developed and thus able to provide an adequate standard of living. There is no established definition of the term "developed" or "developing" in the United Nations system. The World Bank defines developed countries as "(h)igh income countries, in which most people have achieved a high standard of living" while developing countries are defined as "countries with low or middle levels of GNP per capita" [20, p103]. It notes that certain high income countries, however, are classified as developing despite their high per capita income because of their economic structure or the official opinion of their government. The International Monetary Fund divides the world into two major groupings - advanced economies, and emerging markets and developing countries. However, it acknowledges that these groupings are not based on strict criteria but rather have evolved over time [21]. Any such binary grouping is at best a gross simplification of the diverse spectrum of economic and social development which exists. 
The United Nations Development Programme produces annually the Human Development Report, which ranks countries according to their overall level of human development. They measure human development as a combination of life expectancy, literacy and education rates, and economic development. Those countries with combined high levels of these indicators are classified as having high human development. The Human Development Index is useful as it acknowledges that economic and social development requires more than achieving a high national income. This Human Development Index is also not bound by historical, political or geographical groupings, and thus classes countries such as Chile, Qatar, Mexico, and Tonga as having high human development along side countries more generally considered developed, such as those located in Western Europe plus the US, Canada, Australia, New Zealand and Japan.

Estimating the minimum water requirement to sustain a high level of development is also problematic due to synergies between the different water uses. A reduction of water consumption in one sector may be compensated by growth in another. Where a country increasingly depends upon food imports (virtual water), which in less developed countries are dominated by bulk grain imports, a decline in commercial agricultural water consumption may be accompanied by growth of domestic water consumption as urban and peri-urban communities seek to meet a greater proportion of basic fresh food needs locally. Synergies may be even more significant within the non-agricultural economy - the decline of a water intensive manufacturing industry will lead to the decline of related industries down the supply chain. Thus, growing water scarcity may impact upon water efficient industries by affecting indirectly their competitive advantage. 
There are two approaches for estimating the minimum amount of water required to sustain a high level of human development. One approach is to examine water usage rates in countries with high human development in order to identify the minimum threshold of water usage required to sustain a high level of human development. Effectively, this is an examination of the development efficiency ratio of water usage to identify the lowest ratio that permits the achievement of high human development. This development-efficiency approach is appropriate for estimating both a minimum domestic water consumption threshold well as a minimum overall threshold of water consumption for economic and social development. This approach has the advantage that it is based upon water consumption figures of actual nations and thus incorporates the synergies that exist between different sectors in those nations. Conversely, it has the disadvantage that it will also incorporate water usage by any water intensive industries maintained for social or historical reasons specific to the countries being studied. This disadvantage can be minimised by excluding agricultural water consumption where agricultural output is insignificant in its contribution to GDP or employment.

A second approach for estimating the minimum amount of water required to sustain a high level of human development is to examine the water intensity of different economic sectors and then estimate hypothetically the minimum water requirements overall of a water efficient developed economy. This could be termed a sectoral approach. This approach has the advantage over the development efficiency approach that it allows the industries that produce maximum economic output per unit of water to be identified, hence allowing 
the elimination of less water efficient industries (that some water scarce countries may maintain for social or historical reason) from consideration and thus producing a lower and potentially more accurate estimate of real minimum water requirements. However, it has the disadvantage that it ignores the interdependencies that exist between water efficient and water intensive sectors, which may only partially be eliminated by international trade in water intensive commodities. Since this approach compares different economic sectors it cannot be used to identify minimum water requirements solely within the domestic water supply sector.

\subsection{Estimating minimum domestic water requirements}

An examination globally of the development efficiency ratio of domestic water consumption (domestic consumption measured in 1/c/d divided by the HDI value) reveals a ratio ranging from 2.7 in Ethiopia through to 1051 in Armenia. Amongst countries with high human development the development efficiency ratio for domestic water consumption ranges from 86.9 in the Netherlands through to 809.8 in Canada. Thus countries such as Ethiopia and the Netherlands use domestic water relatively efficiency compared to Canada or Armenia.

Amongst countries with high human development Uruguay has the lowest per capita domestic consumption rate of $61 \mathrm{l} / \mathrm{c} / \mathrm{d}$, followed by the Netherlands with $82 \mathrm{l} / \mathrm{c} / \mathrm{d}$ and the UK with 95 1/c/d, while Canada has the highest consumption of 769 1/c/d [10, 22]. Thus, there is little correlation between GDP per capita and domestic water usage in countries of 
high human development. Above a relatively low threshold water usage does not impact on quality of life, however, determining that threshold precisely is difficult.

Household water-use data for the Netherlands and the UK from local sources does not match precisely FAO data. ${ }^{1}$ Water consumption in the Netherlands is $124 \mathrm{l} / \mathrm{c} / \mathrm{d}$ [23] and in the UK 151 1/c/d [24]. Average household water-use in the Netherlands breaks down to 52 1/c/d for bathing, $36 \mathrm{l} / \mathrm{c} / \mathrm{d}$ for toilet flushing, $20 \mathrm{l} / \mathrm{c} / \mathrm{d}$ for clothes washing, $8.7 \mathrm{l} / \mathrm{c} / \mathrm{d}$ for food preparation and dish washing, $1.6 \mathrm{l} / \mathrm{c} / \mathrm{d}$ for drinking, and $6.4 \mathrm{l} / \mathrm{c} / \mathrm{d}$ for other uses [23]. This breakdown suggests that even lower per capita water consumption is achievable. Efficient dual flush toilets can use as little as $2 / 4$ litres per flush, suggesting $15 \mathrm{l} / \mathrm{c} / \mathrm{d}$ could be sufficient for this use, while recycling shower water for toilet flushing could entirely eliminate the use of $36 \mathrm{l} / \mathrm{c} / \mathrm{d}$ of freshwater. Other more efficient household appliances could result in further consumptive savings. Data from the Netherlands suggests that $85 \mathrm{l} / \mathrm{c} / \mathrm{d}$ are sufficient to support a high quality of life.

\subsection{Estimating minimum economic water requirements}

Estimating the water required to sustain a modern economy is more difficult than estimating minimum water domestic water requirements to sustain a high quality of life. Taking the development-efficiency approach reveals that industrial water usage amongst countries with high human development ranges from as little as 3.4 1/c/d in Malta and 12 1/c/d in Cyprus to 2,810 1/c/d in Canada and 2,882 1/c/d in Bulgaria [10, 22]. Moreover,

\footnotetext{
${ }^{1}$ Local data from Uruguay was not readily obtainable.
} 
even in extremely water scarce countries, industrial water consumption varies significantly, from 13.7 1/c/d in Kuwait to 127 1/c/d in the United Arab Emirates (UAE).

Water-use data for Malta from local sources does not match precisely FAO data, with domestic consumption being $81 \mathrm{l} / \mathrm{c} / \mathrm{d}$ [25]. This is a level very similar to the minimum domestic water requirement estimated above based upon Dutch consumption patterns. Other non-agricultural water-use totals $44 \mathrm{l} / \mathrm{c} / \mathrm{d}$ and is distributed fairly evenly between the industrial $(12 \mathrm{l} / \mathrm{c} / \mathrm{d})$, tourism $(11 \mathrm{l} / \mathrm{c} / \mathrm{d})$, government $(12 \mathrm{l} / \mathrm{c} / \mathrm{d})$, commercial $(7.4 \mathrm{l} / \mathrm{c} / \mathrm{d})$ and other $(1.61 / \mathrm{c} / \mathrm{d})[25]$.

The situation in Malta suggests that a water efficient non-agricultural economy can function effectively and support a high level of human and economic development with less than $125 \mathrm{l} / \mathrm{c} / \mathrm{d}$, not allowing for water distribution losses. Malta's economic development is little dependent upon agriculture or agricultural water usage, with the agricultural sector in Malta consuming only $6.6 \mathrm{l} / \mathrm{c} / \mathrm{d}$ while contributing $2.4 \%$ to GDP [26]. Thus, although there may be some economic synergies between the agricultural and non-agricultural economy, the contribution of agriculture to Malta's overall economic development is as similarly insignificant as the sector's water consumption. Furthermore, including Malta's agricultural water consumption in overall water consumption figures when estimating minimum water requirements for social and economic development has little impact on the final result.

Using data from other countries with high human development and very low industrial water consumption is problematic as their relatively high domestic consumption may 
include some industrial / commercial water usage, thus giving an unrealistically low estimate of industrial / commercial water consumption. For example, industrial / commercial water use in Bahrain is $42.5 \mathrm{l} / \mathrm{c} / \mathrm{d}$ but domestic fresh water use in Bahrain is $355 \mathrm{l} / \mathrm{c} / \mathrm{d}$ [27]. (Agricultural water use in Bahrain is insignificant as is agriculture's contribution to Bahraini GDP.) In Cyprus, another country with very low industrial water consumption, significant agricultural and domestic water consumption may incorporate some industrial consumption; domestic freshwater use is $250 \mathrm{l} / \mathrm{c} / \mathrm{d}$, agricultural water use is $231 \mathrm{l} / \mathrm{c} / \mathrm{d}$, while other non-agricultural uses total $19.2 \mathrm{l} / \mathrm{c} / \mathrm{d}$ [28]. Thus synergies between the different sectors make using such countries to calculate the minimum water requirements for a non-agricultural economy problematic given the significance of these other sectors water consumption rates.

Use of the sectoral approach to estimate minimum water requirements for sustain a modern economy is limited by a lack of data showing a detailed breakdown of water consumption by different sectors for most countries. However, data from the UK is available which shows a breakdown of water consumption by economic sector and sub-sectors. The Electricity and Gas sector accounts for $50.3 \%$ of water usage [29]. This is mainly used for cooling purposes, a function performed almost entirely by sea water in some water scarce countries such as Cyprus [28]. The UK's service sector consumes only 3.8 percent of total water consumption despite making up 79.3 percent of economic activity [29]. It consumes approximately $29.6 \mathrm{l} / \mathrm{c} / \mathrm{d}$ of water. The construction sector is also relatively water efficient, consuming 0.12 percent but contributing 5.1 percent of economic activity. Similarly, the more water efficient of the manufacturing industries (rubber and plastics, electrical 
equipment and transport equipment manufacture) consume 0.42 percent of water but contribute 5.8 percent of economic activity [30]. The construction sector and these relatively water efficient manufacturing industries together consume approximately 4.2 1/c/d.

In total, $34 \mathrm{l} / \mathrm{c} / \mathrm{d}$ of water supports approximately 90 percent of economic activity, a very small amount considering the relatively plentiful water resources of the UK and the lack of water scarcity in much of the country to serve as a driver for greater efficiency. While this disregards economic interdependencies, competitive advantage suggests that an extremely water scarce country can specialise its economy in non-water intensive industry and services while trading for water intensive agricultural and industrial products. Just as agricultural needs have increasingly been met through the importation of food (or "virtual water") in water scarce regions, water intensive manufactured goods are also being imported to water scarce regions.

The above analysis suggests that as little as $35 \mathrm{l} / \mathrm{c} / \mathrm{d}$ are required to sustain a water efficient non-agricultural economy able to provide a high quality of life. Including basic domestic water requirements increases this to $120 \mathrm{l} / \mathrm{c} / \mathrm{d}$ before water system distribution losses are considered.

\section{Water system losses and other uses of water}


All water distribution systems have some system losses. Within Europe water losses vary from as high as 50 percent in Bulgaria and 40 percent in Slovenia, to as little as ten percent in Denmark and three percent in Germany [31]. Singapore also has extremely low water system losses, with unaccounted for water of only five percent [32]. Continuous maintenance and renewal of water distribution systems is required with a complex interaction of the types of pipes used, surrounding environment and operational conditions all influencing the rate at which a distribution network must be renewed to maintain a given level of water losses [33]. Since some level of water losses are an integral part of any water distribution system, allowance for low level water losses must be considered when calculating minimum water requirements. A rate of ten percent, the rate achieved by Denmark, is perhaps a realistic target for most countries and should therefore be incorporated into the minimum water requirement estimate.

Brooks [5] makes the argument that the human right to water should be extended to include sufficient water to grow nutritious food for a healthy life. Given the extent that even the least developed countries in the world are now integrated to a greater or lesser extent into global food markets and the fact that some such countries now make extensive use of such markets to satisfy basic food needs, the argument that there is a human right to sufficient water for food self-sufficiency is difficult to sustain. Clearly some countries from across the development spectrum successfully satisfy nutritious food requirements for a healthy life for their people without being food self-sufficient. However, Brooks' argument does have merit. Imported grains alone do not allow for a nutritious diet and it doubtful that least developed countries have the financial resources to import significant quantities of other 
foods. Even in more wealthy countries there may be some benefit in meeting some freshfood requirements locally.

Quantifying water requirements for household or small-scale fresh-food production is difficult since requirements will vary according to climatic conditions, soil types, food preferences and other factors [5]. One of the few such estimates of water for this water use was developed by Shuval [18] in the context of Israel-Palestine. He estimated that $68 \mathrm{l} / \mathrm{c} / \mathrm{d}$ $\left(25 \mathrm{~m}^{3} / \mathrm{c} / \mathrm{y}\right)$ was required for this use. Such a volume of water should generally be able to be met, where necessary, from recycled wastewater given that $68 \mathrm{l} / \mathrm{c} / \mathrm{d}$ is well below the 120 1/c/d basic water requirement to satisfy non-agricultural water needs.

In many countries some freshwater will be required for environmental functions, a water use which Brooks [5] also argues should be considered part of the human right to water. Quantifying the water required for this is again problematic as it will depend heavily upon local environmental conditions. In some contexts treated wastewater may be used if necessary for environmental flows, as occurs in Israel today [34], but it unlikely that a country using the minimum water requirement calculated above would have much treated wastewater available for environmental flows after meeting local fresh-food production requirements. However, in extremely water scarce countries generally little freshwater is naturally present in the environment due to aridity, suggesting that environmental flow requirements would be minimal. Further research quantifying the extent to which recycled wastewater water could be sufficient for satisfying basic fresh-food production and 
environmental functions in regions of extreme water scarcity would be useful although the results will depend significantly on local conditions.

\section{Conclusions}

Both a sectoral approach - based on estimating hypothetically the minimum water requirements overall of a water efficient economy through an examination of different economic sectors, and a development efficiency approach - based upon identifying the minimum threshold of water usage required to sustain high human development as demonstrated by countries with high human development, can be used to estimate the minimum amount of water required for social and economic development. Using both approaches allows the results of each to be cross checked and verified.

The preceding analysis suggests that a country could meet its domestic water requirements together with its water requirements for maintaining a water efficient non-agricultural economy capable of sustaining a high level of human development with as little as 120 1/c/d. Low (but not exceptionally low) water distribution losses of approximately ten percent suggest that another 10 to $15 \mathrm{l} / \mathrm{c} / \mathrm{d}$ of water would be required. Therefore, a minimum of $135 \mathrm{l} / \mathrm{c} / \mathrm{d}$ is required for social and economic development that would permit the achievement of high human development.

According to FAO data only Kuwait and the UAE presently fall below this $135 \mathrm{l} / \mathrm{c} / \mathrm{d}$ threshold, and only two other countries, the Bahamas and Qatar, (both with high human 
development) have less than $270 \mathrm{l} / \mathrm{c} / \mathrm{d}$ [10]. At least in part the high human development achieved by Kuwait, UAE and Qatar is due to the significant income they receive from petroleum exports. However, as some extremely water-scarce states lacking petroleum reserves have demonstrated, achieving social and economic development in the face of significant water constraints is possible. Malta with only 346 1/c/d has achieved high human development. The Maldives with only 274 1/c/d has achieved medium human development and an economic growth rate of 10.8 percent in 2004 . Jordan with only $430 \mathrm{l} / \mathrm{c} / \mathrm{d}$ has also achieved medium human development and a growth rate of 7.7 percent in 2004 [22, 35].

Improving desalination technologies are decreasing the cost of domestic and industrial water supply in extremely water scarce areas. An example of the decreasing cost of desalination is the recently opened desalination plant in Ashkelon, Israel run by Veola Water which produces fresh water at cost of $€ 0.50$ (\$US0.64) per cubic metre [36]. While this is the price paid for water at the desalination plant and does not include distribution costs, it suggests that meeting minimum water requirements for social and economic development by desalination should already be affordable where necessary for all but the least economically developed countries, none of whom should require the use of desalination to meet their minimum water requirements for the foreseeable future if water resources are efficiently allocated on a national basis and are similarly used in an efficient manner. Where populations are located distant to naturally available freshwater resources but in coastal areas or areas with brackish groundwater, desalination should already be affordable in most cases for meeting minimum water requirements. 
Plentiful water is clearly beneficial for national development and it is clearly imperative that global per capita freshwater resources remain adequate to support sufficient water intensive agriculture and industry for meeting global needs. However, on a national basis water resource scarcity alone need not hinder development given that all countries either have significantly more water resources available to them than are required to satisfy minimum water requirements for social and economic development (as calculated above), or their existing level of economic development means desalination can affordably meet such requirements. The problem is not water scarcity per se, rather it is effective human organisation which is critical in ensuring sufficient water availability for domestic needs and for facilitating economic development [37].

\section{Acknowledgements}

The author of this paper would like to express his gratitude to the referees for their valuable comments which permitted the paper to be refined prior to publication.

\section{References:}

1. United Nations, United Nations Millennium Declaration, United Nations General Assembly, New York, 2000.

2. United Nations Commission on Sustainable Development, The Johannesburg Declaration on Sustainable Development: Draft Political Declaration, United Nations Commission on Sustainable Development, Johannesburg, 2002.

3. World Health Organization, Guidelines for Drinking-water Quality: incorporating first addendum, 3rd ed., World Health Organization, Geneva, 2006. 
4. United Nations Committee on Economic Social and Cultural Rights, General Comment No. 15 (2002): The right to water (arts. 11 and 12 of the International Covenant on Economic, Social and Cultural Rights), http://www.unhchr.ch/html/menu2/6/cescr.htm, 2002.

5. D. Brooks, Human rights to water in North Africa and the Middle East: What's new and what isn't; what's important and what's not. International Journal of Water Resources Development, 23 (2007), in press.

6. World Water Assessment Programme, Water for People, Water for Life: The United Nations World Water Development Report, UNESCO publishing / Berghahn Books, Paris, 2003.

7. J. Chenoweth, International River Basin Management: Data and Information Exchange under International Law and the Case of the Mekong River Basin, Journal of Energy and Natural Resources Law, 18 (2000), 142-158.

8. International Law Association, Helsinki Rules on the uses of the waters of international rivers, International Law Association, London, 1967.

9. International Law Commission, Convention on the Law of the Non-navigational Uses of International Watercourses, United Nations Webserver: http://www.un.org/law/ilc/texts/nonnav.htm, 1997.

10. Food and Agriculture Organization, Aquastat: FAO's Information System on Water and Agriculture, http://www.fao.org/ag/agl/aglw/aquastat/dbase/index.stm, 2004.

11. T. Allan, The Middle East water question: Hydropolitics and the global economy. I.B. Tauris, London, 2001.

12. Food and Agriculture Organization, FAOSTAT - Nutritional Data, http://faostat.fao.org/faostat/collections?subset=nutrition, 2006.

13. Food and Agriculture Organization, The state of agricultural commodity markets, Food and Agriculture Organization, Rome, 2004.

14. A. Chapagain and A. Hoekstra, Water Footprints of Nations: Volume 1: Main Report, UNESCO-IHE Delft, Delft, 2004.

15. WHO / UNICEF Joint Monitoring Programme for Water Supply and Sanitation, Global Water Supply and Sanitation Assessment 2000 Report. WHO / UNICEF, Washington, 2000.

16. P.H. Gleick, Basic water requirements for human activities: Meeting basic needs, Water International, 21 (1996) 83-92.

17. G. Howard and J. Bartram, Domestic Water Quantity, Service, Level and Health. World Health Organization, Geneva, 2003.

18. H. Shuval, Approaches to Resolving the Water Conflicts Between Israel and her Neighbors - A Regional Water-for-Peace Plan, Water International, 17 (1992) 122143.

19. M. Falkenmark, Fresh water - time for a modified approach, Ambio, 15(1986) 192200.

20. V.S. Avtonomov and T.P. Soubbotina, The World and Russia: Materials for Reflection and Discussion, Washington DC, World Bank, 1999.

21. International Monetary Fund, World Economic Outlook, International Monetary Fund, Washington DC, 2006. 
22. United Nations Development Programme, Human Development Report 2006, Oxford University Press, New York, 2006.

23. VEWIN, Waterleidingstatistiek 2005, Vereniging van Waterbedrijven in Nederland, Rijswijk, 2006.

24. OFWAT, Security of supply, leakage and the efficient use of water: 2004-05, Office of Water Services (OFWAT), Birmingham, 2005.

25. National Statistics Office, Environment Statistics, National Statistics Office, Valletta, 2002.

26. National Statistics Office, Structural Indicators: 4th quarter 2005, National Statistics Office, Valletta, 2006.

27. Ministry of Electricity and Water, Statistical Book 2003, Ministry of Electricity and Water, Bahrain, 2003.

28. Statistical Service, Environmental Statistics 2006, Statistical Service, Nicosia, 2006.

29. National Statistics, The Blue Book 2002, HMSO, London, 2002.

30. National Statistics, Mid 1998 population estimates, Population Trends, 98 (1999) 91-93.

31. European Environment Agency, Losses from urban water networks, http://dataservice.eea.europa.eu/atlas/viewdata/viewpub.asp?id=517, 2006

32. National Environment Agency, Towards Environmental Sustainability: State of the Environment 2005 Report Singapore, National Environment Agency, Singapore, 2005.

33. Y. Kleiner, B.J. Adams, and J.S. Rogers, Water Distribution Network Renewal Planning. ASCE Journal of Computing in Civil Engineering, 15 (2001), 15-26.

34. J. Chenoweth, Setting sustainable goals for environmental remediation: The case of River Remediation in Israel, Ecological Restoration, 24 (2006) 158-164.

35. World Bank. Key development data and statistics, http://web.worldbank.org/WBSITE/EXTERNAL/DATASTATISTICS/0, , contentM DK:20535285 menuPK:1192694 pagePK:64133150 piPK:64133175 theSitePK:2 39419,00.html, 2006.

36. Veolia Water, Veolia Water starts up operation of the world's largest reverse osmosis seawater desalination plant in Ashkelon (Israel), http://www.veoliawaterst.com/en/press/?news=1127\&src=vw_group, 2005.

37. J. Chenoweth, Reassessing the standard indicator of national water scarcity. Water International, in press. 
Table 1: Minimum per capita water requirement estimates

\begin{tabular}{|l|l|l|}
\hline Author & $\begin{array}{l}\text { Estimate } \\
(\mathbf{l} / \mathbf{c} / \mathbf{d})\end{array}$ & Basis of estimate \\
\hline WHO / UNCEF (2000) & 20 & Basic domestic health and hygiene needs \\
\hline Gleick (1996) & 50 & Basic domestic health and hygiene needs \\
\hline Howard and Batram (2003) & 100 & All domestic health and hygiene needs \\
\hline Shuval (1992) & 342 & Non-agricultural requirements plus water for \\
\hline Falkenmark (1986) & 1,369 & Requirement to run a modern society \\
\hline World Water Assessment & 4,654 & Drinking water for active and healthy human \\
Programme (2003) & & life \\
\hline
\end{tabular}

